\title{
Leishmaniasis transmission in an ecotourism area: potential vectors in Ilha Grande, Rio de Janeiro State, Brazil
}

Bruno Moreira Carvalho ${ }^{1 *}$, Michele Maximo², Wagner Alexandre Costa ${ }^{1}$, Antonio Luís Ferreira de Santana', Simone Miranda da Costa ${ }^{1}$, Taiana Amancio Neves da Costa Rego ${ }^{3}$, Daniela de Pita Pereira ${ }^{3}$ and Elizabeth Ferreira Rangel ${ }^{1}$

\begin{abstract}
Background: The south coast of Rio de Janeiro State, in Brazil, is endemic for cutaneous and visceral leishmaniases and is frequently visited by tourists from different parts of the world. Since the complex epidemiology of leishmaniases demands local studies, the goal of this study was to investigate the phlebotomine sand fly fauna and leishmaniases transmission in Ilha Grande, an ecotourism area of Angra dos Reis municipality.

Methods: Sand fly fauna was sampled in three monitoring stations using HP light traps in domiciles, peridomiciles and forests. Species abundance was evaluated by the Index of Species Abundance. A Leishmania natural infection survey was done using multiplex PCR and dot blot hybridization.

Results: During 15 consecutive months of sand fly monitoring, 1093 specimens from 16 species were captured. The potential leishmaniases vectors found were Lutzomyia (Nyssomyia) intermedia, L. migonei, L. (N.) flaviscutellata, L. (Psychodopygus) ayrozai and L. (Lutzomyia) longipalpis. Five species were new records in Ilha Grande: L. (Sciopemyia) microps, L. termitophila, L. firmatoi, L. rupicola and L. (P.) ayrozai. Higher species richness was found inside forest areas, although potential leishmaniases vectors were present in deforested areas, peridomiciles and inside houses. Lutzomyia (N.) intermedia and L. migonei were the most abundant species. Females of L. migonei showed a high rate (10.3\%) of natural infection by Leishmania (Viannia) sp., probably Leishmania (V.) braziliensis.

Conclusions: The detection of leishmaniases transmission and potential vectors in Ilha Grande is of public health concern, especially because tourists are frequently visiting the island. Besides reinforcing the epidemiological importance of $L$. (N.) intermedia in Rio de Janeiro State, the role of L. migonei in cutaneous leishmaniasis transmission is highlighted with its high rate of Leishmania natural infection. The finding of $L$. (L.) longipalpis confirmed the human autochthonous case of visceral leishmaniasis from the island. The presence of $L$. (N.) flaviscutellata in peridomestic areas is also an important finding, since the species is involved in the transmission of diffuse cutaneous leishmaniasis. Health education practices directed to the local community and tourists are important control actions that can be taken in Ilha Grande to reduce the burden of leishmaniases.
\end{abstract}

Keywords: Sand fly vectors, Touristic area, Visceral leishmaniasis, Cutaneous leishmaniasis, Rio de Janeiro

\footnotetext{
* Correspondence: brunomc@ioc.fiocruz.br

'Laboratório de Transmissores de Leishmanioses, Instituto Oswaldo Cruz, Fundação Oswaldo Cruz. Av. Brasil, 4365, Pavilhão Carlos Chagas, $5^{\circ}$ andar, sala 43 - Manguinhos, Rio de Janeiro, RJ 21040-360, Brasil

Full list of author information is available at the end of the article
} 


\section{Background}

Phlebotomine sand flies are insects (Diptera: Psychodidae) known for their role in leishmaniases transmission to man, as well as bartonellosis and numerous arboviruses. In the Neotropical region, approximately 500 species are described, with about 20 of them related to leishmaniases transmission $[1,2]$.

In endemic regions, leishmaniases show a diffuse distribution, composed by smaller, local transmission foci. The diversity of vector, parasite and host species involved in the transmission cycles contribute to the complex epidemiology of these diseases. Therefore, environmental changes caused by human or natural events affect local populations of these species and can influence disease risk [3,4].

Leishmaniases are being considered as emerging diseases in travelers. In a study of imported human cases in non-endemic countries, South America was considered the main area for the acquisition of cutaneous leishmaniasis, with adventure travelers on long-term trips to forested areas at higher risk of infection [5].

In Rio de Janeiro State, Brazil, the majority of cutaneous leishmaniasis (CL) human cases are caused by Leishmania
(Viannia) braziliensis. The most abundant sand fly species in the state's transmission foci is Lutzomyia (Nyssomyia) intermedia, but other potential vector species are also present: L. migonei, L. (N.) whitmani, L. (Pintomyia) fischeri and $L$. (N.) flaviscutellata. Human cases of visceral leishmaniasis (VL) are also reported in the state, which are caused by Leishmania (Leishmania) infantum chagasi, and transmitted by its main vector, Lutzomyia (Lutzomyia) longipalpis [6,7].

The south coast of Rio de Janeiro State is a very attractive place for tourists seeking the natural beauties of the Atlantic Forest, but it is also the second region of the state most affected by CL, after the metropolitan region. A recent study demonstrated that Angra dos Reis, a municipality in the state's south coast, is one of the most vulnerable to impacts on diseases caused by climate and environmental change, including CL [8].

In Angra dos Reis municipality the main destination of tourists is Ilha Grande ("Big Island"). This island has records of sporadic CL human cases since the first outbreak, which occurred in the small fisherman community of Praia Vermelha in $1975[9,10]$. The first sand fly survey of the

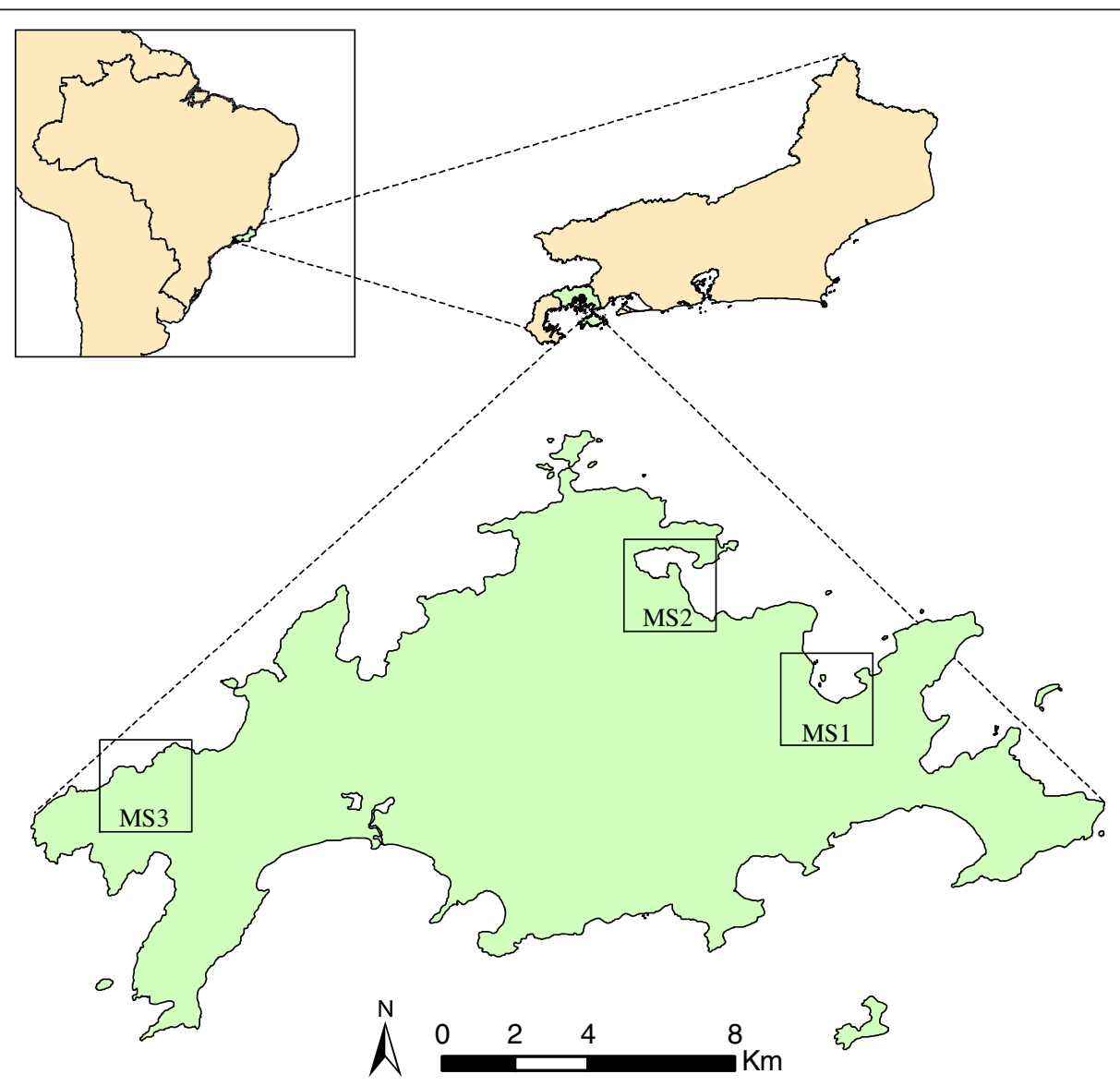

Figure 1 Location of Ilha Grande in Brazil and Rio de Janeiro State. Sand fly monitoring stations are highlighted as MS1: Vila do Abraão, MS2: Enseada das Estrelas and MS3: Praia Vermelha. 
island was published by Araújo Filho et al. [11,12], who detected potential CL vector species, such as $L$. (N.) intermedia, L. migonei, and L. (N.) flaviscutellata. The other captured species, without known medical importance, were Brumptomyia cunhai, B. nitzulescui, L. edwardsi, L. lanei, L. pascalei and L. (Micropygomyia) schreiberi. The authors also detected $L$. (L.) longipalpis, but at the time no human case of VL had been recorded on the island.

In 2005, the first and only VL human case of Ilha Grande was recorded in a fisherman's village at Enseada das Estrelas, approximately $20 \mathrm{~km}$ away of Praia Vermelha, where L. (L.) longipalpis had been detected in the late 1970s by Araújo Filho \& Sherlock [13]. Following the notification of this VL case, the Health Department of Angra dos Reis Municipality (FuSAR) performed sand fly surveys on the area, as part of the entomologic surveillance activities. The surveys detected only CL vector species: $L$. (N.) intermedia, L. migonei and L. (P.) fischeri. As the VL main vector $L$. (L.) longipalpis was not found, the case was left opened in the Ministry of Health's Disease Notification System (SINAN). Besides the cited species, FuSAR also has records of $L$. (N.) whitmani and $L$. (P.) pessoai occurrence from other parts of the island [14].
Another sand fly survey conducted in Ilha Grande was a study by Souza et al. [15], who detected L. (N.) intermedia, L. migonei, L. tupynambai, L. pelloni, L. (M.) schreiberi and Brumptomyia sp. in Vila do Abraão. Caldellas [16] performed a canine serological survey on the island and also captured $L$. (N.) intermedia and $L$. migonei in peridomestic areas of Enseada das Estrelas and Vila do Abraão.

Since Ilha Grande is an ecotourism area that receives travelers from many parts of the world, it is important to study the local transmission of infectious diseases. Therefore, the goal of this study was to investigate the phlebotomine sand fly fauna and leishmaniases transmission in the island, which has records of human cases of both CL and VL.

\section{Methods}

\section{Study area}

Ilha Grande is the greatest continental island of Rio de Janeiro State, with area of approximately $193 \mathrm{~km}^{2}$. It is located between coordinates $23^{\circ} 5^{\prime}-23^{\circ} 14^{\prime}$ south and $44^{\circ}$ $51-44^{\circ} 23^{\prime}$ west, in the Atlantic Forest biome, in Angra dos Reis municipality (Figure 1). The island is mainly

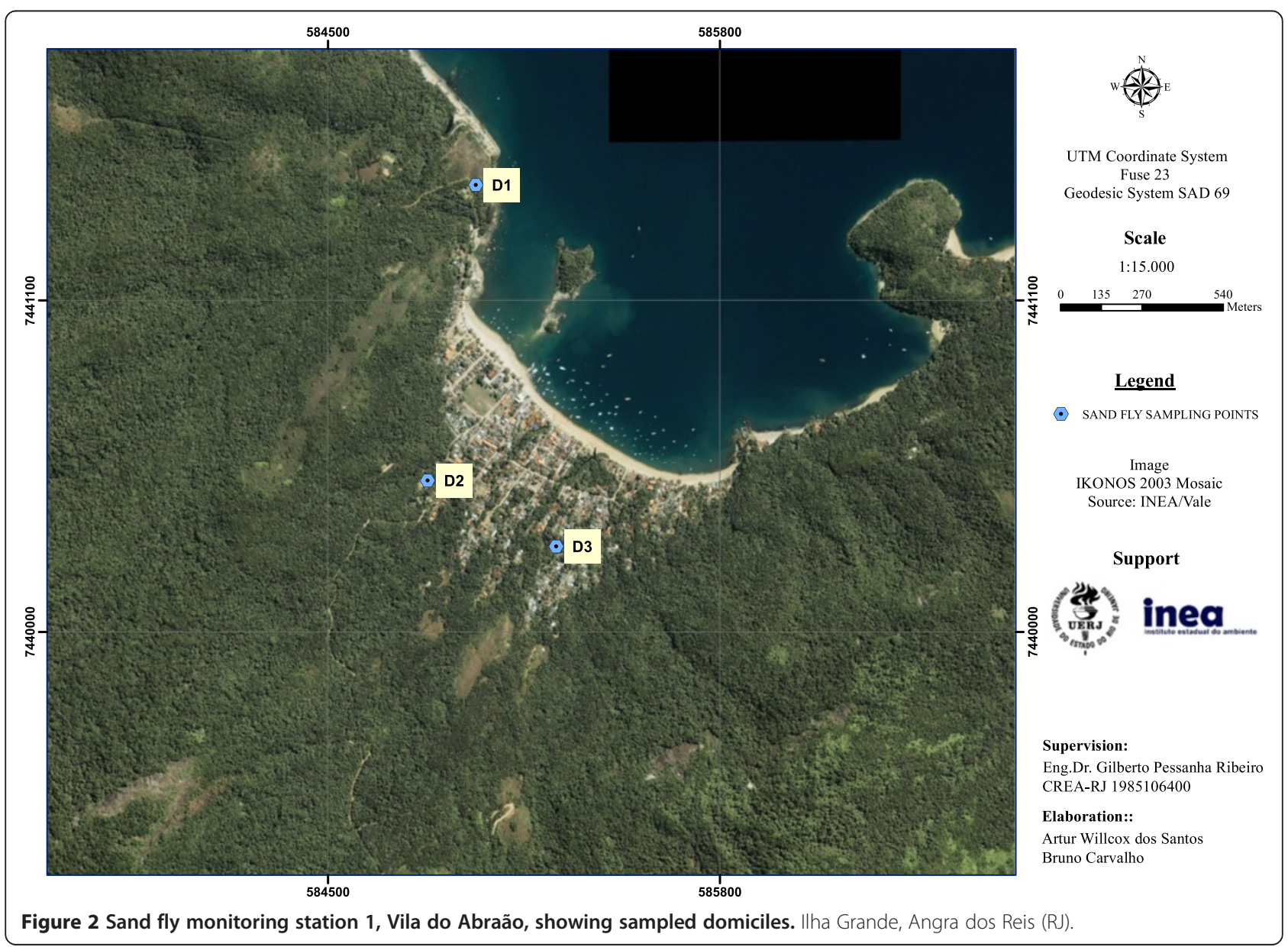


covered by dense ombrophilous forest, and also in smaller proportions, secondary forests, sandy ridges, mangroves and herbaceous vegetation on rocky outcrops. The weather is typically tropical, with higher temperature and precipitation during summer. The annual precipitation is high (over 2,000 $\mathrm{mm}$ ), with frequent extreme rain events [17]. A few months before the start of this study, in January 2010, a great natural disaster struck the island, when huge landslides occurred in several localities. One of the studied localities was directly affected by these landslides, the community of Praia Vermelha.

The island has a population of 9,000 residents, spread in small villages near beaches. The Atlantic Forest cover is in different regeneration levels due to human occupation and use in the past for agriculture through crops of sugar cane, coffee and corn [18]. Four Environmental Preservation Areas exist on the island to protect the natural ecosystems and have restrictive rules for land use, so touristic activities are considered ecotourism. In fact, ecotourism is the main economic activity of the island, which attracts people from different parts of the world [19].

\section{Sand fly survey}

Three monitoring stations were established to sample the sand fly fauna monthly: Vila do Abraão (MS1), Enseada das Estrelas (MS2) and Praia Vermelha (MS3) (Figure 1). Sporadic CL human cases are recorded in the three localities. Enseada das Estrelas is the only locality of the island with a recorded VL human case. Leishmania infections were also detected in dogs in the three localities $[11,15,16]$, as well as in sylvatic and synanthropic rodents in Praia Vermelha [20].

On each monitoring station, three domiciles were sampled (D1-D9) (Figures 2, 3, 4). The peridomestic area of sampled domiciles were very similar, having features which are likely to be suitable for sand fly breeding, such as dirt floor, fruitful trees and secondary forest. Some residences also had dogs, cats and chicken, and some dwellers commented that wild animals often appear near houses, e.g. opossums and rodents. Two additional sampling points were established at MS2 to capture sand flies for a Leishmania natural infection experiment (E1-E2) (Figure 3). Geographic coordinates of sampling points were obtained with a GPS receiver Garmin e'Trex Vista HCx, in SAD69 Datum (Table 1).

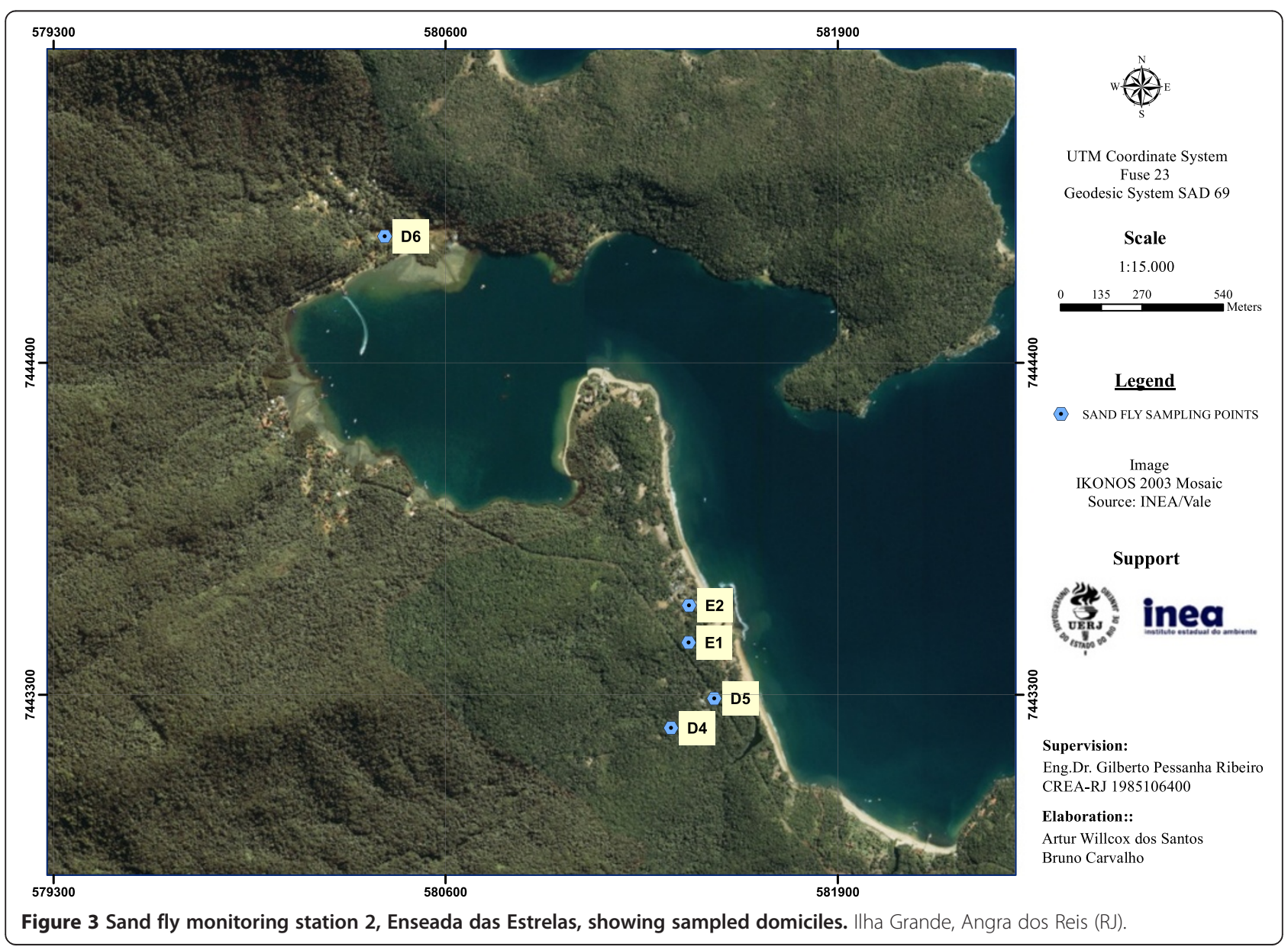




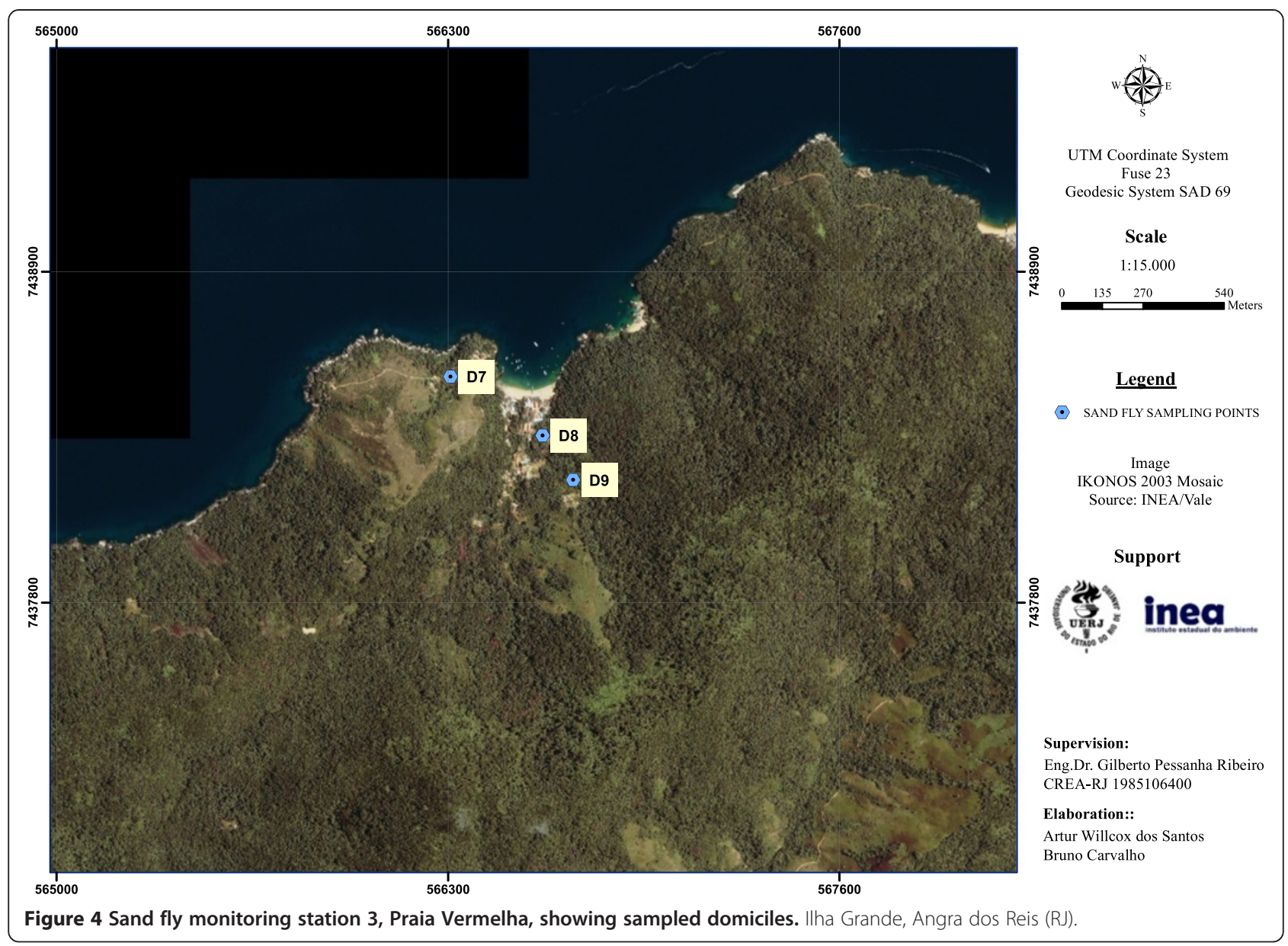

By looking at the three satellite images on the same scale (Figures 2, 3, 4), it is clear that MS1 has the largest deforested area. Vila do Abraão is known as the capital of the island and concentrates most tourism-related establishments (e.g. hotels, restaurants, stores and boat trip agencies). It is where the majority of tourists arrive at the island. The increase in tourism activities has contributed to a disorganized population growth with lack of proper infrastructure [19]. Comparatively, MS2 and MS3 are smaller fisherman villages, with less deforested area.

Captures were conducted monthly between July 2010 and September 2011. On each sampled domicile, three HP light traps [21] were installed: inside the domicile, in the peridomicile and in the nearest forest. The traps were exposed from 17:00 to 08:00, through four consecutive nights each month. Collected sand flies were sent to the laboratory for clarification, mounting in slides and species identification according to Young \& Duncan [22].

In order to compare species abundance in the three monitoring stations, the Index of Species Abundance (ISA) [23] was calculated. This index aggregates infor- mation on relative abundance, as well as spatial distribution of collected individuals. The output values are standardized between 0 and 1 (SISA), so higher values mean the species is more abundant.

\section{Leishmania natural infection}

Sand flies captured in MS2 (E1 and E2) and MS3 (D9) were sent to the laboratory for a Leishmania natural infection survey (58 unfed females and 57 males for contamination control). From each female, the two last abdominal segments were dissected in order to observe the internal genitalia and determinate its species according to Young \& Duncan [22]. Since male species can be determined by observation of the external genitalia, no dissection was needed. The insects were then stored individually in $1.5 \mathrm{ml}$ tubes at $-18^{\circ} \mathrm{C}$ until DNA extraction and further analyzes.

DNA was extracted as previously described [24]. Multiplex Polymerase Chain Reaction (PCR) was designed to simultaneously amplify the cacophony gene IVS6 region (which is used as an internal control for the polymerase enzyme activity and DNA extraction in Lutzomyia sand flies), and the conserved kinetoplast 
Table 1 Geographic coordinates of sand fly sampling points

\begin{tabular}{|c|c|c|c|}
\hline Monitoring station & Sampling point & Latitude & Longitude \\
\hline \multirow[t]{3}{*}{ MS1 } & D1 & S 23007'59.6" & W 44010'11.6' \\
\hline & D2 & S $23^{\circ} 08^{\prime} 31.5^{\prime \prime}$ & W $44^{\circ} 10^{\prime} 17.0^{\prime \prime}$ \\
\hline & D3 & 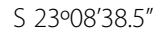 & 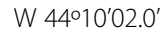 \\
\hline \multirow[t]{5}{*}{ MS2 } & D4 & S $23^{\circ} 07^{\prime} 04.7^{\prime \prime}$ & 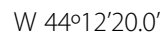 \\
\hline & D5 & S $23^{\circ} 07^{\prime} 01.5^{\prime \prime}$ & W 44ำ $12^{\prime} 15.0^{\prime \prime}$ \\
\hline & D6 & S $23^{\circ} 06^{\prime} 11.9^{\prime \prime}$ & W 441'ㄷ․ \\
\hline & E1 & S 230.6'55.5" & W 44012'18.0 \\
\hline & E2 & S $23^{\circ} 06^{\prime} 51.1^{\prime \prime}$ & 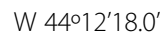 \\
\hline \multirow[t]{3}{*}{ MS3 } & D7 & S 23009'38.0" & W $44^{\circ} 21^{\prime} 08.0^{\prime \prime}$ \\
\hline & D8 & S 23009'44.3" & W 44020'57. \\
\hline & D9 & S 23009'49.1" & W 44020'53.6' \\
\hline
\end{tabular}

MS1: Vila do Abraão; MS2: Enseada das Estrelas; MS3: Praia Vermelha.

DNA minicircle region from Leishmania spp. The amplified products further underwent dot blot hybridization with a Leishmania (Viannia)-specific biotinylated probe [24].

Rigorous procedures were assumed in order to control potential contamination: i) individual male sand flies were included as negative control in the DNA extraction step and in the PCR step; ii) DNA of artificially infected females were included as positive control; iii) all instruments and working areas were decontaminated with diluted chloride solution and ultraviolet light.

\section{Results}

During the period of study, 1093 sand flies were captured from 16 species (Table 2). Four potential CL vectors were detected: $L$. (N.) intermedia, L. migonei, $L$. (N.) flaviscutellata and $L$. (P.) ayrozai. The main VL vector was also captured, $L$. (L.) longipalpis.

Besides having the largest number of captured specimens, Enseada das Estrelas (MS2) had the highest species richness $(S=16)$. In Vila do Abraão $(M S 1), 111$ specimens were captured from 11 species. Praia Vermelha (MS3) also had 11 species detected, with 421 specimens captured. Lutzomyia (N.) intermedia and L. migonei were present in the three monitoring stations. Lutzomyia (N.) flaviscutellata was present in MS1 and Enseada das Estrelas (MS2); L. (L.) longipalpis and L. (P.) ayrozai were found only in MS2 (Table 2).

The most abundant species in MS1 were $L$. (M.) schreiberi $(\mathrm{SISA}=0.37), L$. migonei $(\mathrm{SISA}=0.36)$ and $L$. tupynambai (SISA $=0.35)$. In MS2, L. migonei $(\mathrm{SISA}=0.64$ ) was

Table 2 Sand fly abundance and richness in monitoring stations

\begin{tabular}{|c|c|c|c|c|c|c|c|c|c|c|c|c|}
\hline \multirow[t]{2}{*}{ Species } & \multicolumn{3}{|c|}{ MS1 } & \multicolumn{3}{|c|}{ MS2 } & \multicolumn{3}{|c|}{ MS3 } & \multicolumn{3}{|c|}{ Total } \\
\hline & $\bar{M}$ & $\mathbf{F}$ & $M+F$ & $M$ & $\mathbf{F}$ & $\overline{M+F}$ & $M$ & $\mathbf{F}$ & $M+F$ & $M$ & $\mathbf{F}$ & $M+F$ \\
\hline Brumptomyia cunhai & 3 & 0 & 3 & 17 & 12 & 29 & 4 & 2 & 6 & 24 & 14 & 38 \\
\hline Brumptomyia nitzulescui & 6 & 2 & 8 & 2 & 6 & 8 & 3 & 2 & 5 & 11 & 10 & 21 \\
\hline Brumptomyia spp. & 1 & 0 & 1 & 0 & 1 & 1 & 0 & 2 & 2 & 1 & 3 & 4 \\
\hline Lutzomyia (Lutzomyia) longipalpis* & 0 & 0 & 0 & 2 & 1 & 3 & 0 & 0 & 0 & 2 & 1 & 3 \\
\hline Lutzomyia (Sciopemyia) microps & 0 & 0 & 0 & 0 & 2 & 2 & 0 & 1 & 1 & 0 & 3 & 3 \\
\hline Lutzomyia edwardsi & 1 & 6 & 7 & 14 & 49 & 63 & 1 & 6 & 7 & 16 & 61 & 77 \\
\hline Lutzomyia migonei* & 4 & 3 & 7 & 13 & 75 & 88 & 186 & 87 & 273 & 203 & 165 & 368 \\
\hline Lutzomyia tupynambai & 2 & 29 & 31 & 3 & 38 & 41 & 0 & 5 & 5 & 5 & 72 & 77 \\
\hline Lutzomyia termitophila & 0 & 0 & 0 & 0 & 2 & 2 & 0 & 0 & 0 & 0 & 2 & 2 \\
\hline Lutzomyia firmatoi & 0 & 7 & 7 & 8 & 19 & 27 & 1 & 0 & 1 & 9 & 26 & 35 \\
\hline Lutzomyia rupicola & 1 & 0 & 1 & 27 & 41 & 68 & 4 & 15 & 19 & 32 & 56 & 88 \\
\hline Lutzomyia pascalei & 9 & 11 & 20 & 29 & 23 & 52 & 1 & 2 & 3 & 39 & 36 & 75 \\
\hline Lutzomyia pelloni & 0 & 0 & 0 & 5 & 20 & 25 & 0 & 0 & 0 & 5 & 20 & 25 \\
\hline Lutzomyia (Nyssomyia) flaviscutellata* & 1 & 4 & 5 & 0 & 3 & 3 & 0 & 0 & 0 & 1 & 7 & 8 \\
\hline Lutzomyia (Nyssomyia) intermedia* & 0 & 1 & 1 & 16 & 70 & 86 & 52 & 45 & 97 & 68 & 116 & 184 \\
\hline Lutzomyia (Psychodopygus) ayrozai* & 0 & 0 & 0 & 0 & 2 & 2 & 0 & 0 & 0 & 0 & 2 & 2 \\
\hline Lutzomyia (Micropygomyia) schreiberi & 6 & 14 & 20 & 14 & 42 & 56 & 0 & 2 & 2 & 20 & 58 & 78 \\
\hline Lutzomyia spp. & 0 & 0 & 0 & 1 & 4 & 5 & 0 & 0 & 0 & 1 & 4 & 5 \\
\hline Abundance & 34 & 77 & 111 & 151 & 410 & 561 & 252 & 169 & 421 & 437 & 656 & 1093 \\
\hline Richness & & 11 & & & 16 & & & 11 & & & 16 & \\
\hline
\end{tabular}

Ilha Grande, July 2010 to September 2011.

MS1: Vila do Abraão; MS2: Enseada das Estrelas; MS3: Praia Vermelha; M: Males; F: Females.

*Potential leishmaniases vector species. 
the most abundant, followed by $L$. edwardsi (SISA = 0.64) and $L$. (N.) intermedia (0.60). MS3 had L. (N.) intermedia $(\mathrm{SISA}=0.8)$, L. migonei $(0.73)$ and $L$. rupicola $(\mathrm{SISA}=0.47)$ as most abundant species (Figure 5).

The most common species captured inside houses and in peridomiciles were $L$. migonei, $L$. (N.) intermedia and $L$. (M.) schreiberi. The other potential leishmaniases vectors found, L. (N.) flaviscutellata and L. (L.) longipalpis, also occurred inside houses and in peridomiciles. Lutzomyia (P.) ayrozai occurred only inside the forest (Table 3 ).

Three of 29 (10.3\%) tested L. migonei females had positive results for natural infection with Leishmania (Viannia) sp. They were captured in peridomestic areas of D9, in MS3 (Table 4). The positive reactions for the PCR Multiplex and dot blot hybridization are shown in Figure 6.

\section{Discussion}

The 16 sand fly species found in Ilha Grande corroborate with other studies performed in environmental protection areas of Atlantic Forest, which commonly detect about 10-30 sand fly species [25-27]. The observation of high species richness in forests and less impacted areas

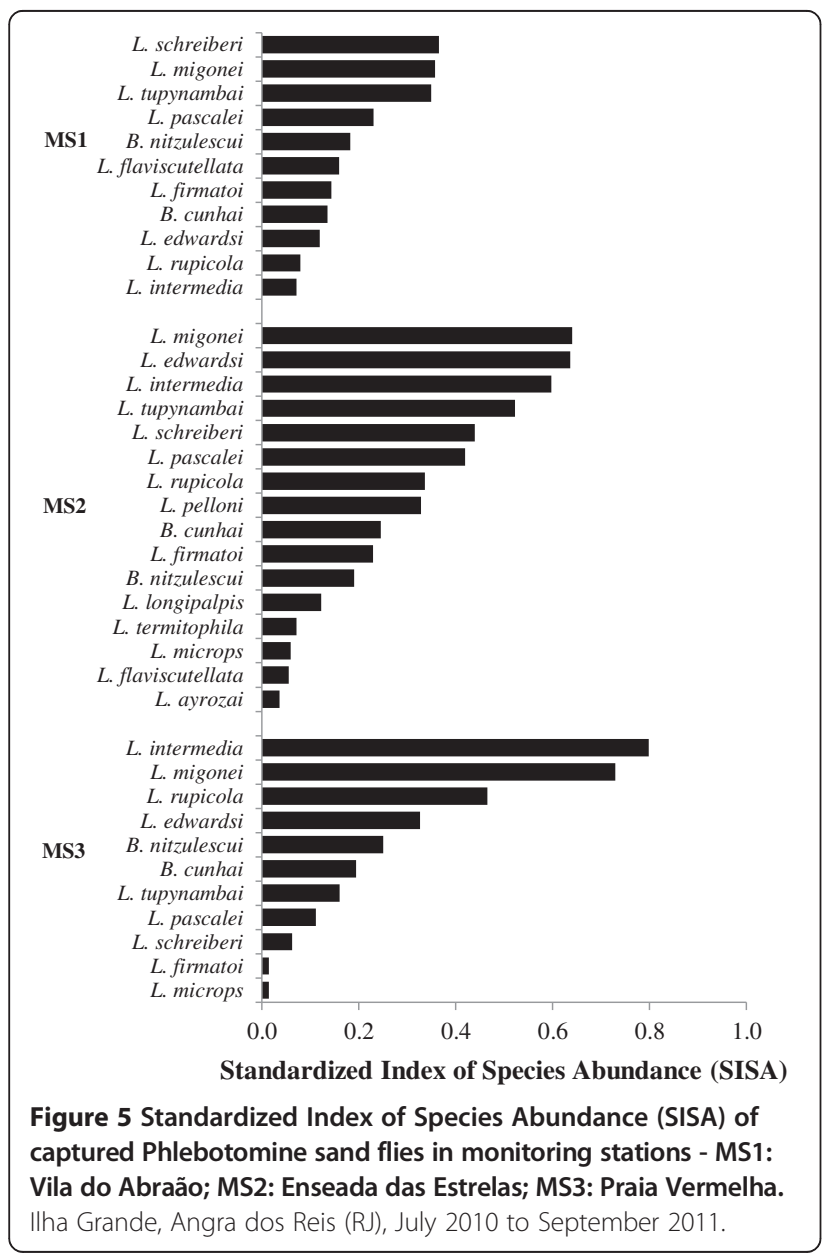

is common in the literature. In Colombia, Travi et al. [28] detected higher species richness in a forest reserve area when compared to captures made in a small village. Similar findings were shown in Brazil by Souza et al. [25], in Rio de Janeiro State, Alessi et al. [29] in São Paulo State and Pinto et al. [27] in Espírito Santo State. These studies also argue that, although species richness is lower, most vector species tend to be present in impacted areas. This is particularly evident in Praia Vermelha, locality with recent deforested areas by the landslides of 2010. The same vector species found in 1978 by Araújo Filho et al. [11,12] remain present in the deforested areas. Therefore, the occurrence of potential vectors L. (N.) intermedia, L. migonei, L. (N.) flaviscutellata and L. (L.) longipalpis in peridomestic areas of Ilha Grande's villages must be highlighted.

Present results contribute with the first record of five species in Ilha Grande: L. (Sciopemyia) microps, L. termitophila, L. firmatoi, L. rupicola and L. (Psychodopygus) ayrozai. This was expected, because Ilha Grande has few published studies about its phlebotomine sand fly fauna, especially involving at least one year of monthly monitoring [14-16]. The exception is the study by Araújo Filho et al. [11,12], who performed sand fly captures in Praia Vermelha for 16 consecutive months. These five species had already been previously detected in Rio de Janeiro State [30] and in other Atlantic Forest areas of Espírito Santo State [27] and Paraná State [31].

The two most abundant species were $L$. (N.) intermedia and L. migonei, captured even inside houses, which was also observed in previous studies from Ilha Grande [11,12,14-16]. These species are considered important vectors of Leishmania (Viannia) braziliensis in Brazil's Southeast region and are commonly captured in high abundance [24,32,33]. Other species found in high abundance, such as L. edwardsi, L. tupynambai and $L$. rupicola, are sylvatic species commonly found in Atlantic Forest areas [26,27,34-36]. Lutzomyia tupynambai was the most abundant sand fly species in forests of Serra da Tiririca State Park, Rio de Janeiro State, which suggests its common occurrence in this habitat [36]. These three species have no recorded evidence of importance in Leishmania transmission cycles. Lutzomyia edwardsi was found naturally infected by Leishmania $(V$.) braziliensis in São Paulo State, but it was not considered epidemiologically important especially because $L$. migonei was predominant in the studied locality [37].

Lutzomyia (N.) intermedia, captured in the three monitoring stations, is considered the main CL vector in Southeast Brazil, including Rio de Janeiro State [2,7]. It is commonly found as the most abundant sand fly species in Rio de Janeiro State [38-40] and in peridomestic areas of São Paulo and Espírito Santo States [2,41]. Its vectorial competence was already determined by findings 
Table 3 Sand fly abundance in domicile, peridomicile and forest

\begin{tabular}{|c|c|c|c|c|c|c|c|c|c|c|c|c|}
\hline \multirow[t]{2}{*}{ Species } & \multicolumn{3}{|c|}{ MS1 } & \multicolumn{3}{|c|}{ MS2 } & \multicolumn{3}{|c|}{ MS3 } & \multicolumn{3}{|c|}{ Total } \\
\hline & $\mathrm{D}$ & $\mathbf{P}$ & $\mathbf{F}$ & D & $\mathbf{P}$ & $\mathrm{F}$ & $\mathrm{D}$ & $\mathbf{P}$ & $F$ & D & $\mathbf{P}$ & $F$ \\
\hline Brumptomyia cunhai & 2 & 0 & 1 & 13 & 3 & 13 & 2 & 3 & 1 & 17 & 6 & 15 \\
\hline Brumptomyia nitzulescui & 0 & 2 & 6 & 2 & 1 & 5 & 1 & 2 & 2 & 3 & 5 & 13 \\
\hline Brumptomyia spp. & 0 & 1 & 0 & 1 & 0 & 0 & 1 & 0 & 1 & 2 & 1 & 1 \\
\hline Lutzomyia (Lutzomyia) longipalpis* & 0 & 0 & 0 & 2 & 1 & 0 & 0 & 0 & 0 & 2 & 1 & 0 \\
\hline Lutzomyia (Sciopemyia) microps & 0 & 0 & 0 & 0 & 0 & 2 & 0 & 1 & 0 & 0 & 1 & 2 \\
\hline Lutzomyia edwardsi & 0 & 2 & 5 & 2 & 16 & 45 & 1 & 2 & 4 & 3 & 20 & 54 \\
\hline Lutzomyia migonei* & 3 & 2 & 2 & 55 & 17 & 16 & 15 & 220 & 38 & 73 & 239 & 56 \\
\hline Lutzomyia tupynambai & 0 & 4 & 27 & 1 & 8 & 32 & 0 & 4 & 1 & 1 & 16 & 60 \\
\hline Lutzomyia termitophila & 0 & 0 & 0 & 1 & 0 & 1 & 0 & 0 & 0 & 1 & 0 & 1 \\
\hline Lutzomyia firmatoi & 0 & 5 & 2 & 24 & 1 & 2 & 0 & 1 & 0 & 24 & 7 & 4 \\
\hline Lutzomyia rupicola & 1 & 0 & 0 & 0 & 3 & 65 & 7 & 8 & 4 & 8 & 11 & 69 \\
\hline Lutzomyia pascalei & 0 & 2 & 18 & 0 & 11 & 41 & 0 & 2 & 1 & 0 & 15 & 60 \\
\hline Lutzomyia pelloni & 0 & 0 & 0 & 5 & 5 & 15 & 0 & 0 & 0 & 5 & 5 & 15 \\
\hline Lutzomyia (Nyssomyia) flaviscutellata* & 0 & 3 & 2 & 0 & 0 & 3 & 0 & 0 & 0 & 0 & 3 & 5 \\
\hline Lutzomyia (Nyssomyia) intermedia* & 0 & 1 & 0 & 29 & 49 & 8 & 31 & 33 & 33 & 60 & 83 & 41 \\
\hline Lutzomyia (Psychodopygus) ayrozai* & 0 & 0 & 0 & 0 & 0 & 2 & 0 & 0 & 0 & 0 & 0 & 2 \\
\hline Lutzomyia (Micropygomyia) schreiberi & 2 & 14 & 4 & 38 & 14 & 4 & 0 & 1 & 1 & 40 & 29 & 9 \\
\hline Lutzomyia spp. & 0 & 0 & 0 & 1 & 2 & 2 & 0 & 0 & 0 & 1 & 2 & 2 \\
\hline Abundance & 8 & 36 & 67 & 174 & 131 & 256 & 58 & 277 & 86 & 240 & 444 & 409 \\
\hline
\end{tabular}

Ilha Grande, July 2010 to September 2011.

MS1: Vila do Abraão; MS2: Enseada das Estrelas; MS3: Praia Vermelha; D: Domicile; P: Peridomicile; F: Forest.

*Potential leishmaniases vector species.

of natural and experimental infection with Leishmania (V.) braziliensis [24,42-44].

The detection of $L$. migonei in high abundance also corroborates with previous studies of Atlantic Forest areas of Southeast Brazil, where it is usually found as the second-most abundant species and it is considered CL secondary vector $[2,7]$. It was first found naturally infected with flagellates by Pessoa \& Coutinho [45] in São Paulo State. Afterwards, in Baturité, Ceará State, Azevedo et al. [46] also detected promastigotes in $0.2 \%$ of dissected L. migonei females, which were later identified as Leishmania (V.) braziliensis [47]. Pita-Pereira et al. [24], using the same molecular method as the present work, detected a $2 \%$ infection rate of L. migonei with Leishmania (V.) braziliensis in Jacarepaguá, Rio de Janeiro. In contrast with these low Leishmania natural infection rates, the high rate of Leishmania (Viannia) sp. infection detected in L. migonei in Praia Vermelha (10.3\%) suggest the role of this sand fly species in CL transmission in this locality. These results complement the previous study of Araújo Filho et al. $[11,12]$, who commented about $L$. migonei importance as CL vector in this locality.

It is also noteworthy that, during this study, the higher abundances of $L$. migone $i$ were observed inside and next to chicken coops in Praia Vermelha, as previously
Table 4 Phlebotomine sand flies submitted to Leishmania natural infection survey

\begin{tabular}{|c|c|c|c|c|c|}
\hline Species & $\begin{array}{c}\text { Monitoring } \\
\text { station }\end{array}$ & Positive & Negative & Total & $\begin{array}{c}\text { Infection } \\
\text { rate (\%) }\end{array}$ \\
\hline $\begin{array}{l}\text { Lutzomyia } \\
\text { edwardsi }\end{array}$ & MS2 & 0 & 6 & 6 & - \\
\hline \multirow{2}{*}{$\begin{array}{l}\text { Lutzomyia } \\
\text { migonei* }\end{array}$} & MS2 & 0 & 1 & 1 & - \\
\hline & MS3 & 3 & 26 & 29 & 10.3 \\
\hline \multirow{2}{*}{$\begin{array}{l}\text { Lutzomyia } \\
\text { tupynambai }\end{array}$} & MS2 & 0 & 2 & 2 & - \\
\hline & MS3 & 0 & 1 & 1 & - \\
\hline \multirow[t]{2}{*}{ Lutzomyia rupicola } & MS2 & 0 & 13 & 13 & - \\
\hline & MS3 & 0 & 1 & 1 & - \\
\hline Lutzomyia pelloni & MS2 & 0 & 2 & 2 & - \\
\hline \multirow{2}{*}{$\begin{array}{l}\text { Lutzomyia } \\
\text { (Nyssomyia) } \\
\text { intermedia* }\end{array}$} & MS2 & 0 & 1 & 1 & - \\
\hline & MS3 & 0 & 2 & 2 & - \\
\hline Total & & 3 & 55 & 58 & 5.2 \\
\hline
\end{tabular}

MS1: Vila do Abraão; MS2: Enseada das Estrelas; MS3: Praia Vermelha; M: Males; F: Females.

*Potential leishmaniases vector species. 


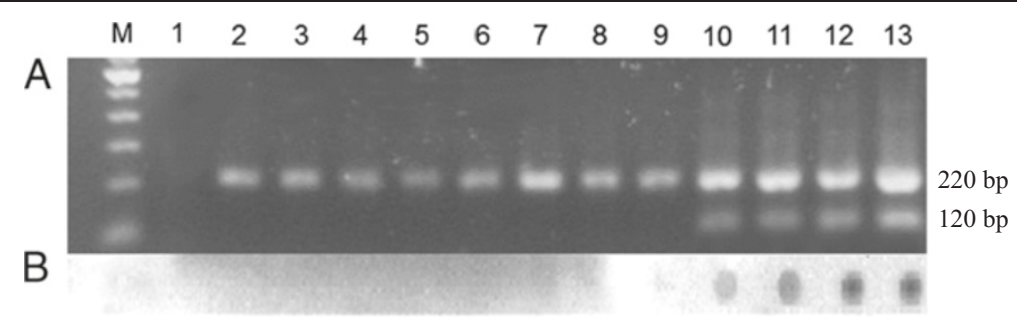

Figure 6 Results of Leishmania natural infection survey. A) 1.5\% agarose gel electrophoresis of Multiplex PCR products. Lanes: M, molecular weight marker (100 bp); 1, negative control; 2-4, Lutzomyia sp. males; 5-9, negative females; 10-12, positive Lutzomyia migonei females; 13, positive control. B) Dot blot hybridization with Leishmania (Viannia)-specific biotinylated probe.

observed by Araújo Filho et al. [11,12] in the same locality. The association between this species and chickens has been observed in other sand fly studies in Southeast Brazil $[32,40]$.

Recently, L. migonei was found naturally infected with Leishmania (L.) infantum chagasi in São Vicente Férrer, Pernambuco State, suggested by the authors to be a potential VL vector in the locality [48]. Guimarães et al. [49] later detected, in the same locality, L. migonei naturally infected with Leishmania (V.) braziliensis. These findings demonstrate the capacity of $L$. migonei to maintain infection with two different species of Leishmania, although more studies are necessary to investigate the possibility of mixed infection and its role in VL transmission.

The occurrence of L. (N.) flaviscutellata in studied peridomestic areas is important, since this species is involved with the transmission of Diffuse Cutaneous Leishmaniasis (DCL), caused by Leishmania (L.) amazonensis. The low abundance observed can be an underestimate, since only light traps were used. This sand fly species is highly attracted to rodents $[2,50]$, so animalbaited traps should be used for its capture, such as Disney traps [12,51]. Although L. (N.) flaviscutellata is predominantly distributed in the Amazon Forest, it was also found in Atlantic Forest areas of São Paulo State [52], Espírito Santo State [27], Bahia State [53] and Pernambuco State [54]. Lutzomyia (N.) flaviscutellata abundance and distribution in Rio de Janeiro State should be better studied, since the first DCL human case of the state was detected in 2007 in Paraty, a neighbor municipality of Angra dos Reis with very similar environmental characteristics to those from Ilha Grande [55].

Lutzomyia (L.) longipalpis was captured in Enseada das Estrelas, the only locality of Ilha Grande with a record of an autochthonous human case of VL. Considered as the main VL vector in Brazil, this species shows high adaptability to man-modified environments, especially because it has eclectic feeding habits and high anthropophily [1]. This sand fly is widely distributed in the country, occurring in especially high abundances in dry regions of Caatinga and Cerrado biomes, where it is frequently captured in peridomestic areas of rural and even urban regions [6,56]. However, in the present work, $L$. (L.) longipalpis was captured in a transition area between secondary forest and a recent deforested area. Its sylvatic origin has been discussed elsewhere [1]. This suggests that, in Ilha Grande, L. (L.) longipalpis is probably more common in forest areas, as it was also found in other Atlantic Forest areas of Rio de Janeiro, Espírito Santo and São Paulo States [36,57-60].

The detection of $L$. (L.) longipalpis was also important for the Health Surveillance of Angra dos Reis Municipality. Since the notification of the VL human case in 2005, it was still open in the Ministry of Health's Disease Notification System, because the vector had not been captured. This finding, coupled with the detection of Leishmania infection in dogs from the locality [16], shows that a Leishmania (L.) infantum chagasi transmission cycle may be present and therefore surveillance must be constant.

Lutzomyia (P.) ayrozai was captured in low abundance inside the forest. This species is considered to be mainly sylvatic, and was already captured in Rio de Janeiro State in forest areas $[25,26,61]$. It is involved in the transmission of Leishmania (V.) naiffi in the Amazon, with rare human cases recorded. This rarity is discussed by Arias et al. [62] and Lainson et al. [63] as a consequence of the low attraction of $L$. (P.) ayrozai to man. In contrast, in areas of Atlantic Forest of southeast Brazil, this sand fly species was considered highly anthropophilic [61,64]. Since only two specimens of $L$. (P.) ayrozai were captured and there are no records of Leishmania (V.) naiffi outside north Brazil, this sand fly species probably doesn't have a major role in leishmaniases transmission in Ilha Grande.

The present study demonstrates the occurrence of CL and VL vectors even after major environmental impacts (such as the landslides of 2010). This suggests that leishmaniases transmission profiles in the area may have shifted from essentially sylvatic to impacted and peridomestic areas, highlighting the need for constant epidemiologic and entomologic surveillance. In addition, Ilha Grande is an ecotourism area with tourists frequently trekking inside forests, where they may be exposed to vector contact. This can easily be reduced with use of 
insect repellents. People who live on the island need to have access to information about leishmaniases transmission, so that peridomestic cleaning can be carried out, to reduce establishment of vector breeding areas. Health education practices with the native population and information for tourists are suggested control actions that can be taken in Ilha Grande to reduce the burden of leishmaniases.

\section{Conclusions}

Besides reinforcing the epidemiological importance of $L$. (N.) intermedia in Rio de Janeiro State, the role of L. migonei in CL transmission is highlighted with the finding of a high natural infection rate by Leishmania (Viannia) sp. The presence of $L$. (N.) flaviscutellata in peridomestic areas is of public health concern, since it is involved in the transmission of a rare and severe form of cutaneous leishmaniasis. The detection of $L$. (L.) longipalpis in the same locality where the only VL human case of Ilha Grande was recorded in 2005 allowed the closure of the case notification in the Ministry of Health's Disease Notification System. This confirmed autochthonous transmission of visceral leishmaniasis in the island. Finally, the first detection of five sand fly species on the island demonstrates the importance of performing entomological surveys in Atlantic Forest areas. The occurrence of leishmaniases vectors in an area highly visited by tourists emphasizes the need for constant surveillance and health education practices.

\section{Abbreviations \\ CL: Cutaneous leishmaniasis; VL: Visceral leishmaniasis; FuSAR: Health Department of Angra dos Reis (Fundação Municipal de Saúde de Angra dos Reis): SINAN: Ministry of Health's Disease Notification System (Sistema de Informação de Agravos de Notificação); ISA: Index of species abundance; SISA: Standardized index of species abundance; PCR: Polymerase chain reaction; MS: Sand fly monitoring station.}

\section{Competing interests}

The authors declare that they have no competing interests.

\section{Authors' contributions}

BMC conceived and designed the study, coordinated and participated in field work, analyzed data and wrote the manuscript; MM provided epidemiological and entomological data; WAC, ALFS and SMC participated in field work; TANCR performed the Leishmania natural infection survey; DPP coordinated the Leishmania natural infection survey; EFR coordinated the study, participating in its conception, design and discussion of results. All authors read and approved the final manuscript.

\section{Acknowledgements}

To Rodolpho Paraguai, Lucia Regina Brahim Paes, Vanderlei Campos and Rodrigo Godoy, who helped in field work. To João Victor Bou Haya, for helping with sand fly species identification. To the staff of The Health Department of Angra dos Reis (especially the entomology lab), and Ilha Grande State Park for the collaboration in the field. To Gilberto Pessanha Ribeiro and Artur Willcox dos Santos, from The State University of Rio de Janeiro for map preparation. To Instituto Oswaldo Cruz (IOC-FIOCRUZ) and Coordenação de Aperfeiçoamento de Pessoal de Ensino Superior (CAPES) for providing financial support.

\section{Author details}

'Laboratório de Transmissores de Leishmanioses, Instituto Oswaldo Cruz, Fundação Oswaldo Cruz. Av. Brasil, 4365, Pavilhão Carlos Chagas, $5^{\circ}$ andar, sala 43 - Manguinhos, Rio de Janeiro, RJ 21040-360, Brasil. ${ }^{2}$ Fundação Municipal de Saúde de Angra dos Reis, Prefeitura Municipal de Angra dos Reis. Praça General Osório 36, Centro, Angra dos Reis, RJ 23900-600, Brasil. ${ }^{3}$ Laboratório de Biologia Molecular e Doenças Endêmicas, Instituto Oswaldo Cruz, Fundação Oswaldo Cruz. Av. Brasil, 4365, Pavilhão Leônidas Deane, sala 209 - Manguinhos, Rio de Janeiro, RJ 21040-360, Brasil.

Received: 4 September 2013 Accepted: 8 November 2013

Published: 13 November 2013

\section{References}

1. Lainson R, Rangel EF: Lutzomyia longipalpis and the eco-epidemiology of American visceral leishmaniasis, with particular reference to Brazil: a review. Mem Inst Oswaldo Cruz 2005, 100(8):811-827.

2. Rangel EF, Lainson R: Proven and putative vectors of American cutaneous leishmaniasis in Brazil: aspects of their biology and vectorial competence. Mem Inst Oswaldo Cruz 2009, 104(7):937-954.

3. Patz JA, Thaddeus KG, Geller N, Vittor AY: Effects of environmental change on emerging parasitic diseases. Int J Parasitol 2000, 30:1395-1405.

4. Dujardin JC: Risk factors in the spread of leishmaniases: towards integrated monitoring? Trends Parasitol 2006, 22(1):4-6.

5. Pavli A, Maltezou HC: Leishmaniasis, an emerging infection in travelers. Int J Infect Dis 2010, 14:e1032-e1039.

6. Brasil. Ministério da Saúde: Secretaria de Vigilância em Saúde Manual de Vigilância e Controle da Leishmaniose Visceral. 2nd edition. Ministério da Saúde: Brasil. Ministério da Saúde; 2006.

7. Brasil. Ministério da Saúde, Secretaria de vigilância em Saúde: Manual de Vigilância da Leishmaniose Tegumentar Americana. 2nd edition. Ministério da Saúde: Brasil. Ministério da Saúde; 2007.

8. Barata MML, Confalonieri UEC: Mapa de vulnerabilidade da população do Estado do Rio de Janeiro aos impactos das mudanças climáticas nas áreas social, saúde e ambiente. Relatório 4 - versão final. http://download.rj.gov.br/ documentos/10112/364217/DLFE-40943.pdf/rel_vulbilidade.pdf.

9. Araújo Filho NA, Coura JR: Leishmaniose Tegumentar Americana na llha Grande, Rio de Janeiro. I. Investigação epidemiológica clínica e laboratorial. Rev Soc Bras Med Trop 1981, 14(4-6):135-143.

10. Araújo Filho NA, Coura JR: Leishmaniose Tegumentar Americana na llha Grande, Rio de Janeiro. II. Prevalência da infecção humana determinada pela intradermoreação de Montenegro. Rev Soc Bras Med Trop 1981, 14(4-6):145-151.

11. Araújo Filho NA, Sherlock IA, Coura JR: Leishmaniose Tegumentar Americana na llha Grande, Rio de Janeiro. V. Observações sobre a biologia dos transmissores em condições naturais. Rev Soc Bras Med Trop 1981, 14(4-6):171-183.

12. Araújo Filho NA, Sherlock IA, Coura JR: Leishmaniose Tegumentar Americana na llha Grande, Rio de Janeiro. VI. Observações sobre frequência horária e variação mensal dos transmissores. Rev Soc Bras Med Trop 1981, 14(4-6):185-195.

13. Araújo Filho NA, Sherlock IA: Nota sobre a presença da Lutzomyia longipalpis (Lutz \& Neiva, 1912) na llha Grande, Estado do Rio de Janeiro, Brasil. Rev Soc Bras Med Trop 1981, 14(1-3):81-83.

14. Maximo M, Sousa Ramos RRC, Paraguai R, Carvalho BM: Vigilância Entomológica na Leishmaniose Tegumentar Americana: Atividades da Fundação Municipal de Saúde de Angra dos Reis, estado do Rio de Janeiro. In XXVII Reunião de Pesquisa Aplicada em Doença de Chagas e XV Reunião de Pesquisa Aplicada em Leishmanioses. Uberaba: Universidade Federal do Triângulo Mineiro; 2011.

15. Souza MB, Carvalho RW, Machado RN, Wermelinger ED: Flebotomíneos de áreas com notificações de casos autóctones de leishmaniose visceral canina e leishmaniose tegumentar americana em Angra dos Reis, Rio de Janeiro, Brasil. Rev Bras Entomol 2009, 53(1):147-150.

16. Caldellas LJM: Investigação sorológica em 40 cães (Canis familiaris) de áreas endêmicas de leishmaniose tegumentar, no município de Angra dos Reis, Rio de Janeiro, no período de maio a junho de 2008, Monograph. Rio de Janeiro: Faculdade de Tecnologia SENAC Rio, Centro Politécnico; 2010.

17. Bastos MB, Callado CH (orgs): O Ambiente da llha Grande. Rio de Janeiro: Ed. UERJ; 2009. 
18. Alho CJR, Schneider M, Vasconcellos LA: Degree of threat to the biological diversity in the Ilha Grande State Park (RJ) and guidelines for conservation. Braz J Biol 2002, 62(3):375-385.

19. Prado RM: As espécies exóticas somos nós: Reflexão a propósito do ecoturismo na llha Grande. Horiz Antropol 2006, 9(20):205-224.

20. Araújo Filho NA, Coura JR, Reis VLL: Leishmaniose Tegumentar Americana na Ilha Grande, Rio de Janeiro. III. Reservatórios silvestres e comensais. Rev Soc Bras Med Trop 1981, 14(4-6):153-161.

21. Pugedo H, Barata RA, França-Silva JC, Silva JC, Dias E: HP: um modelo aprimorado de armadilha luminosa de sucção para a captura de pequenos insetos. Rev Soc Bras Med Trop 2005, 38(1):70-72.

22. Young DG, Duncan MA: Guide to the identification and geographic distribution of Lutzomyia sandflies in Mexico, the West Indies, Central and South America (Diptera: Psychodidae). Mem Am Entomol Ins 1994, $54: 1-881$

23. Roberts DR, Hsi BP: An index of species abundance for use with mosquito surveillance data. Environ Entomol 1979, 8:1007-1013.

24. Pita-Pereira D, Alves CR, Souza MB, Brazil RP, Bertho AL, Figueiredo AB, Britto CC: Identification of naturally infected Lutzomyia intermedia and Lutzomyia migonei with Leishmania (Viannia) braziliensis in Rio de Janeiro (Brazil) revealed by a PCR multiplex non-isotopic hybridisation assay. Trans R Soc Trop Med Hyg 2005, 99:905-913.

25. Souza NA, Vilela ML, Andrade-Coelho CA, Rangel EF: The phlebotominae sand fly (Diptera: Psychodidae) fauna of two Atlantic Rain Forest Reserves in the State of Rio de Janeiro, Brazil. Mem Inst Oswaldo Cruz 2001, 96(3):319-324

26. Afonso MS, Costa WA, Azevedo ACR, Costa SM, Vilela ML, Rangel EF: Data on sand fly fauna (Diptera, Psychodidae, Phlebotominae) in Itatiaia National Park, Rio de Janeiro State, Brazil. Cad Saude Pub/ 2007, 23(3):725-730

27. Pinto IS, Santos CB, Ferreira AL, Falqueto A: Richness and diversity of sand flies (Diptera, Psychodidae) in an Atlantic rainforest reserve in southeastern Brazil. J Vector Ecol 2010, 35(2):325-332.

28. Travi BL, Adler G, Lozano M, Cadena H, Montoya-Lerma J: Impact of Habitat Degradation on Phlebotomine (Diptera: Psychodidae) of Tropical Dry Forests in Northern Colombia. J Med Entomol 2002, 39(3):451-456.

29. Alessi CAC, Galati EAB, Alves JR, Corbett CEP: American cutaneous leishmaniasis in the Pontal of Paranapanema-SP, Brazil: ecological and entomological aspects. Rev Inst Med Trop S Paulo 2009, 51(5):277-282.

30. Carvalho BM: Aspectos da ecologia de potenciais vetores de leishmanioses (Diptera: Psychodidae: Phlebotominae) na llha Grande, Angra dos Reis, Rio de Janeiro, MS dissertation. Rio de Janeiro: Fundação Oswaldo Cruz, Instituto Oswaldo Cruz; 2011. http://arca.icict.fiocruz.br/handle/icict/6324.

31. Marcondes CB, Santos-Neto LG, Lozovei AL: Ecology of Phlebotomine sandflies (Diptera, Psychodidae) in Brazilian Atlantic Forest. Rev Soc Bras Med Trop 2001, 34(3):255-260.

32. Rangel EF, Souza NA, Wermelinger ED, Azevedo ACR, Barbosa AF, Andrade C: Flebótomos de Vargem Grande, Foco de Leishmaniose Tegumentar do Estado do Rio de Janeiro. Mem Inst Oswaldo Cruz 1986, 81(3):347-349.

33. Camargo-Neves VL, Gomes AC, Antunes JL: Correlação da presença de espécies de flebotomíneos (Diptera: Psychodidae) com registros de casos da leishmaniose tegumentar Americana no Estado de São Paulo, Brasil. Rev Soc Bras Med Trop 2002, 35(4):299-306.

34. Azevedo ACR, Vilela ML, Souza NA, Andrade-Coelho CA, Barbosa AF, Firmo ALS, Rangel EF: The sand fly fauna (Diptera: Psychodidae: Phlebotominae) of a focus of cutaneous leishmaniasis in Ilhéus, State of Bahia, Brazil. Mem Inst Oswaldo Cruz 1996, 91(1):75-79.

35. Donalisio MR, Peterson AT, Costa PL, Silva FJ, Valença HF, Shaw JJ, Brandão FS: Microspatial distributional patterns of vectors of cutaneous leishmaniasis in Pernambuco, Northeastern Brazil. J Trop Med 2012, 2012:642910.

36. Rodrigues AAF, Barbosa VA, Andrade Filho JD, Brazil RP: The sandfly fauna (Diptera: Psychodidae: Phlebotominae) of the Parque Estadual da Serra da Tiririca, Rio de Janeiro, Brazil. Mem Inst Oswaldo Cruz 2013, 108(7):943-946.

37. Superintendência de Controle de Endemias (Sucen): Encontro de Lutzomyia edwardsi infectada na região da Grande de São Paulo. Rev Saude Publ 2005, 39(1):137-138.

38. Souza MB, Cardoso PG, Sanavria A, Marzochi MCA, de Carvalho RW, Ribeiro PC, Ponte CS, Meira AM, Meródio JC: Fauna flebotomínica do município de Bom Jardim, Região Serrana do estado do Rio de Janeiro, Brasil. Rev Bras Parasitol Vet 2003, 12(4):150-153.
39. Moutinho FF, Souza MB, Carvalho RW: Flebotominos de las zonas endémicas de Leishmaniasis cutánea americana en Paraty, Rio de Janeiro, Brasil. Rev Colomb Entomol 2010, 36(1):82-85.

40. Gouveia C, Oliveira RM, Zwetsch A, Motta-Silva D, Carvalho BM, Santana AF, Rangel EF: Integrated Tools for American Cutaneous Leishmaniasis Surveillance and Control: intervention in an endemic area in Rio de Janeiro, RJ, Brazil. Interdiscip Perspect Infect Dis 2012, 2012:568312.

41. Andrade-Filho JD, Galati EAB, Falcão AL: Nyssomyia intermedia (Lutz \& Neiva, 1912) and Nyssomyia neivai (Pinto, 1926) (Diptera: Psychodidae: Phlebotominae) geographical distribution and epidemiological importance. Mem Inst Oswaldo Cruz 2007, 102(4):481-487.

42. Rangel EF, Souza NA, Wermelinger ED, Barbosa AF: Infecção natural de Lutzomyia intermedia (Lutz \& Neiva, 1912) em área endêmica de leishmaniose tegumentar no Estado do Rio de Janeiro. Mem Inst Oswaldo Cruz 1984, 79(3):395-396.

43. Rangel EF, Barbosa AF, Andrade CA, Souza NA, Wermelinger ED: Development of Leishmania (Viannia) braziliensis Viannia, 1991 in Lutzomyia intermedia (Lutz \& Neiva, 1912) (Diptera: Psychodidae) under experimental conditions. Mem Inst Oswaldo Cruz 1992, 87(2):235-238.

44. Rocha LS, Falqueto A, Santos CB, Ferreira AL, Graça GC, Grimaldi G Jr, Cupolillo E: Survey of natural infection by Leishmania in sand fly species collected in southeastern Brazil. Trans R Soc Trop Med Hyg 2010, 104(7):461-466.

45. Pessoa SB, Coutinho JO: Infecção natural de Phlebotomus migonei por formas leptomonas, provavelmente da Leishmania braziliensis. Rev Biol Hyg 1949, 10:139-142.

46. Azevedo AC, Rangel EF, Queiroz RG: Lutzomyia migonei (Franca 1920) naturally infected with peripylarian flagellates in Baturité, a focus of cutaneous leishmaniasis in Ceará State, Brazil. Mem Inst Oswaldo Cruz 1990, 85:479.

47. Queiroz RG, Vasconcelos AW, Vasconcelos A, de Sousa RN, Pessoa FA, de Alencar JE, David JR: Phlebotomine sand fly (Diptera: Psychodidae) fauna survey in an American cutaneous leishmaniasis ( $\mathrm{ACL}$ ) focus in Baturité, Ceará State, northeast Brazil. Parassitologia 1991, 33:159-167.

48. Carvalho MR, Valença HF, Silva FJ, Pita-Pereira D, Araújo Pereira T, Britto C, Brazil RP, Brandão Filho SP: Natural Leishmania infantum infection in Migonemyia migonei (França, 1920) (Diptera: Psychodidae: Phlebotominae) the putative vector of visceral leishmaniasis in Pernambuco State, Brazil. Acta Trop 2010, 116(1):108-110.

49. Guimarães VCFV: Avaliação da infecção natural de flebotomíneos (Diptera: Psychodidae) por Leishmania spp. no Município de São Vicente Férrer, Pernambuco, MS dissertation. Recife: Fundação Oswaldo Cruz, Centro de Pesquisas Aggeu Magalhães; 2011. http://www.cpqam.fiocruz.br/bibpdf/ 2011 guimaraes-vcfv.pdf.

50. Lainson R, Shaw JJ: Evolution, classification and geographical distribution. In The Leishmaniases in Biology and Medicine, Volume I, Biology and Epidemiology. Edited by Peters W, Killick-Kendrick R. London: Academic; 1987:1-120.

51. Dorval MEC, Alves TP, Cristaldo G, Rocha HC, Alves MA, Oshiro ET, Oliveira AG, Brazil RP, Galati EAB, Cunha RV: Sand fly captures with Disney traps in area of occurrence of Leishmania (Leishmania) amazonensis in the State of Mato Grosso do Sul, mid-western Brazil. Rev Soc Bras Med Trop 2010, 43(5):491-495.

52. Vexenat JA, Barretto AC, Cuba CC, Marsden PD: Características epidemiológicas da leishmaniose tegumentar americana em uma região endêmica do estado da Bahia. III. Fauna Flebotomínica. Mem Inst Oswaldo Cruz 1986, 81(3):293-301

53. Gomes AC, Galati EAB, Classer CM: Nota sobre encontro de phlebotominae (Diptera: Psychodidae) no litoral sul do estado de São Paulo, Brasil. Rev Saude Publ 1990, 24(4):319-320.

54. Balbino VQ, Coutinho-Abreu IV, Sonoda IV, Marques da Silva W, Marcondes CB: Phlebotomine sandflies (Diptera: Psychodidae) of the Atlantic forest in Recife, Pernambuco state, Brazil: the species coming to human bait, and their seasonal and monthly variations over a 2-year period. Ann Trop Med Parasitol 2005, 99(7):683-693.

55. Azeredo-Coutinho RBG, Conceição-Silva F, Schubach A, Cupolillo E, Quintela LP, Madeira MF, Pacheco RS, Valete-Rosalino CM, Mendonça SCF: First report of diffuse cutaneous leishmaniasis and Leishmania amazonensis infection in Rio de Janeiro State, Brazil. Trans R Soc Trop Med Hyg 2007, 101:735-737.

56. Rangel EF, Vilela ML: Lutzomyia longipalpis (Diptera, Psychodidae, Phlebotominae) and urbanization of visceral leishmaniasis in Brazil. Cad Saude Publ 2008, 24(12):2948-2952. 
57. Brazil RP, Pontes MCQ, Passos WL, Rodrigues AAF, Brazil BG: The sand fly fauna (Psychodidae: Phlebotominae) in the region of Saquarema, State of Rio de Janeiro, Brazil, an endemic area of cutaneous leishmaniasis transmission. J Vector Ecol 2011, 36(Suppl 1):S95-S98.

58. Novo SPC, Souza MB, Villanova CB, Meródio JC, Meira AM: Survey of sandfly vectors of leishmaniasis in Marambaia Island, municipality of Mangaratiba, State of Rio de Janeiro, Brazil. Rev Soc Bras Med Trop 2013, 46(2):231-233.

59. Cutolo AA, Camargo DA, Von Zuben CJ: Novos registros de Lutzomyia longipalpis (Lutz \& Neiva, 1912) (Diptera: Psychodidae) na região Centro-Leste do estado de São Paulo, Brasil. Rev Bras Parasitol Vet 2009, 18(1):62-65.

60. Pinto IS, Ferreira AL, Valim V, Carvalho FS, Silva GM, Falcão AL, Dietze R, Falqueto A: Sand fly vectors (Diptera, Psychodidae) of American visceral leishmaniasis areas in the Atlantic Forest, State of Espírito Santo, southeastern Brazil. J Vector Ecol 2012, 37(1):90-96.

61. Aguiar GM, Soucasaux T: Aspectos da ecologia dos flebótomos do Parque Nacional da Serra dos Órgãos, Rio de Janeiro. I. Frequência mensal em isca humana (Diptera, Psychodidae, Phlebotominae). Mem Inst Oswaldo Cruz 1984, 79(2):197-209.

62. Arias JR, Miles MA, Naiff RD, Povoa MM, de Freitas RA, Biancardi CB, Castellon EG: Flagellate infections of Brazilian sand flies (Diptera: Psychodidae): isolation in vitro and biochemical identification of Endotrypanum and Leishmania. Am J Trop Med Hyg 1985, 34(6):1098-1108.

63. Lainson R, Shaw JJ, Silveira FT, Braga RR, Ishikawa EAY: Cutaneous leishmaniasis of man due to Leishmania (Viannia) naiffi. Ann Parasitol Hum Comp 1990, 65:282-284.

64. Aguiar GM, Vilela ML, Soucasaux T: Aspectos da ecologia dos flebótomos do Parque Nacional da Serra dos Órgãos, Rio de Janeiro. V. Preferências alimentares (Diptera, Psychodidae, Phlebotominae). Mem Inst Oswaldo Cruz 1986, 81(4):477-479.

doi:10.1186/1756-3305-6-325

Cite this article as: Carvalho et al:: Leishmaniasis transmission in an ecotourism area: potential vectors in llha Grande, Rio de Janeiro State, Brazil. Parasites \& Vectors 2013 6:325

\section{Submit your next manuscript to BioMed Central and take full advantage of:}

- Convenient online submission

- Thorough peer review

- No space constraints or color figure charges

- Immediate publication on acceptance

- Inclusion in PubMed, CAS, Scopus and Google Scholar

- Research which is freely available for redistribution 